\title{
PENDUDUK DAN DEMOKRASI (STUDI KASUS PADA PEMILIHAN GUBERNUR SULAWESI SELATAN TAHUN 2013-2018 DI KECAMATAN SOMBA OPU KABUPATEN GOWA)
}

\author{
Amir Muhiddin ${ }^{1}$ \\ ${ }^{1}$ Program Studi Ilmu Pemerintahan Fakultas Ilmu Sosial dan Ilmu Politik \\ Universitas Muhammadiyah Makassar \\ Jl Sultan Alauddin No 259 Makassar 90221 \\ Telp. 0411-866972 ext. 107. Fax. 0411-8655888 \\ amir.muhiddin@yahoo.co.id
}

\begin{abstract}
This study was to determine the effect of population quality to the quality of democracy in the election of the Governor of South Sulawesi Year 2013-2018. This research is quantitative and sampling techniques, the method used was survey methods, and techniques of data collection is done by questionnaire and documentation. These results indicate that the quality of Population in Gowa Kabuaten views of education and income levels are still low, but the quality of democracy seen from quite high participation of about 75 to 85\%. Quantitatively based regression is mentioned that there is a significant relationship between the quality of the population and the quality of democracy in the Case of South Sulawesi gubernatorial election in 2013 which was held in the District Somba Opu Gowa.
\end{abstract}

Keywords: residents, democracy, political participation.

\begin{abstract}
ABSTRAK
Penelitian ini untuk mengetahui pengaruh kualitas penduduk dengan kualitas demokrasi pada pemilihan Gubernur Sulawesi Selatan Tahun 2013-2018. Penelitian ini adalah penelitian kuantitatif dan teknik sampling, Metode yang digunakan adalah metode Survei, dan teknik pengambilan data dilakukan dengan angket dan dokumentasi. Hasil penelitian ini menunjukkan bahwa Kualitas Penduduk di Kabuaten Gowa dilihat dari tingkat pendidikan dan pendapatan masih rendah, namun kualitas demokrasi dilihat dari partisipasi cukup tinggi sekitar 75 sampai 85\%. Secara kuantitatif berdasarkan uji regresi disebutkan bahwa ada pengaruh yang signifikan antara kualitas penduduk dan kualitas demokrasi dalam Kasus Pemilihan Gubernur Sulawesi Selatan Tahun 2013 yang diselenggarakan di Kecamatan Somba Opu Kabupaten Gowa.
\end{abstract}

Kata kunci: penduduk, demokrasi, partisipasi politik. 


\section{A. PENDAHULUAN}

Indonesia tumbuh secara kauntitatif, tetapi kurang berkembang secara kualitatif, pernyataan ini bukanlah asumsi semata, akan tetapi sebuah realitas. Jumlah penduduk Indonesia berdasarkan sensus penduduk 2010 sebesar 237,6 juta jiwa, jumlah ini menempatkan Indonesia pada urutan keempat setelah China, India, dan Amerika Serikat. Meski angka pertumbuhan penduduk ditekan sedemikian rupa tetap saja penduduk bertambah 2,3 juta pertahun, setara dengan jumlah penduduk Singapura. Yang membedakan penduduk Singapura lebih berkualitas yang diindikasikan melalui Indeks Pembangunan Manusia (IPM) yaitu berada pada urutan 25 , sedangkan Indonesia berada pada posisi 108 dari 177 negara yang di survey. (Bahan Seminar Koaliasi Kependudukan yang diselenggarakan di Makassar Tanggal 6 Desember 2012).

Berkaitan dengan itu, Indonesia sering disebut-sebut sebagai salah satu negara demokrasi terbesar di dunia. Sebutan itu mungkin ada benarnya sebab sekitar 80 persen penduduk Indonesia adalah penduduk wajib pilih, berdasarkan data KPU Pusat per Februari 2013 ada sekitar 190,4 juta penduduk Indonesia merupakan calon pemilih tetap untuk pemilihan legislatif Tahun 2014. Angka ini tentu saja sangat besar dan kalau dihitung-hitung, maka setiap penduduk Indonesia wajib pilih- memilih pemimpin sekurang-kurangnya satu kali dalam sebulan, mulai pemilihan presiden, pemilihan DPR dan DPRD baik pusat, propinsi, dan kabupaten/ kota, selanjutnya pemilihan kepala desa, dewan perwakilan desa, pemilihan ketua RW, belum lagi dihitung pemilihan lain misalnya pemilihan ketua kelas, pemilihan ketua dan pengurus mesjid, pemilihan oganisasi sosial, keagamaan dan sebagainya. Seringnya bangsa Indonesia memilih pemimpin menandai bahwa negara kita adalah negara demokratis dan tentu menjadi salah satu negara terbesar setelah India dan Amerika Serikat.

Jumlah yang terus bertambah, mulai dari penduduk yang terus bertambah, partai politik yang terus bertambah (setelah orde baru) seharusnya akan menghasilkan proses demokrasi dan proses pemilihan pemimpin yang lebih berkualitas, namun demikian kenyataannya menjadi lain, jumlah ternyata hanya menjadi sebuah angan, jumlah menjadi objek para kandidat dan tim sukses untuk merusak citra demokrasi. Mereka yang besar tetapi tidak berkualitas ternyata menjadi santapan bagi kandidat berduit untuk melakukan money politic, menggiring dan memobilisasi mereka ke lapangan untuk berkampanye, memanfaatkan tenaganya untuk berteriak, dan berjuang untuk maksud yang mereka sendiri kurang memahaminya.

Realitas politik kaum miskin dalam jumlah yang besar tentu saja sangat disayangkan, namun demikian tidak boleh juga dibiarkan terus begitu, sebab akibatnya akan menjadi resistensi, terutama dari segi stabilitas politik. Money politic bukan saja mencederai kualitas demokrasi akan tetapi juga menjadi embrio sering lahirnya sengketa pemilu dan pemilukada di tanah air.

Money politic dalam bentuk pemberian uang kepada masyarakat, sering disebut sebagai politik transaksional, yang secara normatif dilarang dalam undang-undang pemilu, akan tetapi nampaknya itu menjadi trend disetiap pemilihan, dimanapun juga, mulai dari pemilihan presiden, pemilihan 
legislatif disemua tingkatan, sampai kepada pemilihan kepala desa.

Maraknya money politic dalam pemilu mengingatkan kita secara kausalitas, bahwa yang memberi adalah yang berduit dan yang menerima itu adalah mereka yang miskin, dua kelompok inilah yang sejak berabad-abad lalu sering menjadi sebab-akibat lahirnya suap menyuap. Dan mengenai hal ini sudah dijelaskan oleh Homans dan Blau dalam teori pertukaran sosial, bahwa orang-orang yang melakukan interaksi sosial, adalah mereka yang saling berharap susuatu, dan sesuatu itu biasanya dalam bentuk materi (Ritzer, 2007).

Memberikan sesuatu kepada masyarakat miskin, bukan saja keharusan akan tetapi juga menjadi tuntutan, sebab secara normatif hal itu sudah diajarkan dalam agama, dan sudah tersirat misalnya dalam undang-undang dasar 1945 pasal 34 (1) bahwa "Fakir miskin dan anakanak yang terlantar dipelihara oleh Negara".

Pemberian yang memang didasarkan pada norma dan kostitusi tentu bukan masalah, akan tetapi pemberian yang dilandasi dengan transaksi yang mengikat untuk merayu atau memaksa masyarakat memilih salah seorang kandidat, tentu ini menjadi masalah dan resistensi konstitusional, oleh sebab itu perlu diceagah perkembangannya, kalau perlu dihilangkan. Peraturan KPU No 01 Tahun 2013 pasal 32 menyebut bahwa "dilarang menjanjikan atau memberikan uang atau materi lainnya kepada peserta kampanye".

Harapan menghilangkan money politic tentu bukan persolan mudah misalnya melalui penambahan, atau perbaikan regulasi pemilu saja, akan tetapi dibutuhkan analisis yang lebih jauh mengenai faktor-faktor penyebab sehingga money politic itu berlangsung terus menerus (sistenible) bahkan cenderung permanen sifatnya.

Money politic diduga disebabkan oleh faktor kemiskinan yang ditandai tingkat pendidikan, tingkat pendapatan, dan tingkat pelaksanaan keberagamaan.dan sepanjang faktor ini tidak dihilangkan maka sepanjang itu pula money politic tetap berlangsung. Uraian ini menunjukkan bahwa money politic karena kemiskinan merupakan ancaman serius bagi demokrasi.

Apakah ada pengaruh kualitas penduduk dengan kualitas demokrasi yang ada di Kecamatan Somba Opu dalam pemilihan Gubernur Sulawesi Selatan Tahun 2013 ?

\section{B. KERANGKA KONSEP}

Selanjutnya perlu juga dikemukakan bahwa penelitian mengenai penduduk dan demokrasi sudah pernah diteliti oleh peneliti sebelumnya, salah satu diantaranya Dahlian seperti ditulis oleh Haidar Fitra Siagian, dan Ishaq Rahman (2013) yang berkesimpulan bahwa ada hubungan antara pemilih dengan partsispasi politik, baik di negara maju yang ekonomi dan demokrasinya mapan maupun di negara berkembang yang belum mapan ekonomi dan demokrasinya. Disimpulkan bahwa beberapa negara berkembang dengan penduduk yang kurang berkualitas tetapi tingkat partisipasi politiknya tinggi seperti Turki (93,87\%), Vietnam (99,51\%), Rwanda (98,50\%), Cuba $(93,44 \%)$ dan Etiopia $(93,44 \%)$. Bandingkan dengan Amerika Serikat, yang kualitas penduduknya sangat baik, kondang demokrasi memiliki tingkat partisipasi politik yang rendah $(41,59 \%$ pada pemilu legislatif 2010), dan (57,5\% pada pemilihan presiden tahun2012), bahkan negara peringkat ketujuh paling 
demokratis yaitu Swiss hanya $(49,10 \%)$ pada pemilu legislatif 2011.

Jika kualitas penduduk rendah dan tingkat partisipasi poltik tinggi, tentu ini menjadi masalah yang menarik, sebab secara rasional, seharusnya kualitas penduduk yang tinggi juga akan mengahsilkan kualitas demokrasi yang tinggi. Realitas sosial dan politik ini tentu saja masalah dan perlu dicari pemecahannya, sebab apabila tidak, tentu akan menimbulkan resistensi bagi demokrasi itu sendiri, berdasar pada masalah tersebut penelitian ini penting untuk dilakukan.

\section{METODE PENELITIAN}

Penelitian ini adalah penelitian kuantitatif bertujuan menganalisis tentang pengaruh kualitas penduduk dan kualitas demokrasi pada pemilihan Gubernur Sulawesi Selatan di Kecamatan Somba Opu Kabupaten Gowa. Adapun variabel variabel bebas (X) adalah kualitas penduduk yang terdiri dari tingkat pendidikan, tingkat pendapatan, dan tingkat pelaksanaan keberagamaan, sementara itu variabel terikat adalah kualitas demokrasi yang ditandai dengan tingkat partisipasi politik dan ada tidaknya money politic (Y).

Populasi dalam penlitian ini adalah warga Kecamatan Somba Opu yang termasuk Daftar Pemilih Tetap Pemilihan Gubernur Sulawesi Selatan Tahun 2013 di Kabupaten Gowa yang berdasarkan data KPU Kabupaten Gowa berjumlah 97.914 orang.

Adapun teknik sampling yang digunakan dalam penelitian ini adalah teknik random sampling dimana jumlah populasi sebesar 97.914 orang akan diambil $1,1 \%$ sehingga total sampel adalah 1000 Orang, Metode yang digunakan adalah metode Survei, dan teknik pengambilan data dilakukan dengan angket.

Kabupaten Gowa dipilih karena merupakan kabupaten terbesar ketiga dilihat dari jumlah penduduknya setelah Kota Makassar dan Kabupaten Bone, dan Kecamatan. Sementara itu jumlah pemilih di Kabupaten Gowa pada pemilihan Gubernur 2013-2018 sebanyak 506.233 terdiri dari 245.149 dan 261.084.

Kecamatan Somba Opu dipilih sebagai lokasi penelitian karena kecamatan ini merupakan salah satu kecamatan terbesar di Kabupaten Gowa dilihat dari jumlah dan daftar pemilih tetap dalam pilgub Sulawesi Selatan Tahun 2013-2018. Sebagaimana diketahui bahwa di Kecamatan Somba Opu pada pemilihan Gubernur Tahun 2013 terdapat 97.914 daftar pemilihn tetap terdiri dari laki-laki 47.641 dan perempuan 50.273 orang.

Pengolahan dan Analisis Data dilakukan dengan menggunakan statistik deskriptif dan statistik inferensial. Teknik analisis deskriptif dilakukan untuk seluruh indikator maupun peritem dalam hal-hal yang ada kaitannya dengan kualitas penduduk. Teknik analisis inferensial digunakan untuk menguji hipotesis penelitian yaitu model regresi ganda untuk mengungkapkan koefesiensi regresi antara variabel bebas dengan variabel terikat.

\section{HASIL DAN PEMBAHASAN}

\section{1) Gambaran Kualitas Penduduk Dan Kualitas Demokrasi di Kabupaten Gowa}

Kabupaten Gowa terdiri dari 18 kecamatan dan 167 desa/kelurahan dengan luas sekitar 1.883,33 kilometer persegi. Jumlah penduduk Kabupten Gowa berdasar Sensus penduduk Tahun 2010, sebesar 652.942 jiwa, termasuk 
terbesar ketiga di Sulawesi-selatan setelah kota Makassar (1.352.136 jiwa), dan Kabupaten Bone (724.900). Sementara itu penduduk Kecamatan Somba Opu pada tahun 2011 juga merupakan penduduk terbesar pertama di Kabupaten Gowa yakni sebesar 131.598 jiwa dengan pertumbuhan 6,50,Kecamatan Somba Opu juga memiliki pertumbuhan penduduk tertinggi yakni sebesar 6,50 \% pertahun, lebih tinggi dari pertumbuhan kabupaten Gowa sebesar 2,44\% pertahun.

Berikut ini akan dikemukakan kualitas penduduk di Kabupaten Gowa, khususnya Kecamatan Somba Opu dilihat dari aspek pendidikan, pendapatan, dan tingkat pelaksanaan keberagamaan.

a. Tingkat Pendidikan

Berdasarkan hasil survei sosial ekonomi nasional Tahun 2011, tercatat bahwa penduduk Kabupaten Gowa dari penduduk berumur 10 tahun ke atas , sekitar 13,33 persen tidak/belum pernah sekolah, 20,42 persen yang masih sekolah, dan 66,25 persen sudah tidak sekolah lagi. Bila dilihat dari pendidikan yang ditamatkan ternyata 25,31 persen tidak/belum tamat SD. Penduduk yang menamatkan SD, SLTP, dan SLTA mencapai 56,8 persen sedang diploma 1 ke atas hanya ditamatkan oleh kurang dari total penduduk usia 10 tahun ke atas yang sekolah.

Data di atas menunjukkan bahwa penduduk kabupaten Gowa umumnya (56, 8 persen) berpendidikan atau tamat sekurang-kurangnya SD sampai SLTA., dan 25,31 persen tidak tamat SD. Dan bila dilihat dari angka melek huruf maka Kabupaten Gowa termasuk kabupaten yang tinngi persentasenya. Selain itu dan tentu saja menarik adalah data yang terlihat dimana jumlah usia sekolah yang berumur 10 tahun ke atas, sekitar 13,33 persen tidak/belum pernah sekolah, ini sangat beretentangan dengan upaya pemerintah untuk melaksanakan wajib belajar 9 tahun, dan ada sangsi bagi orang tua yang tidak menyekolahkan anaknya.

Selanjutnya adalah Kecamatan Somba Opu. Meskipun tidak ada data tersedia mengenai tingkat pendidikan di Kecamatan Somba Opu, namun karena letaknya di ibu kota kabupaten Gowa sehingga dapat diperkirakan bahwa tingkat penddikan di Kecamatan Somba Opu jauh lebih baik dari rata-rata tingkat pendidikan Kabupaten Gowa.

Sebagai bahan banding bahwa tingkat pendidikan secara nasional seperti diungkap dalam makalah Kasnawi (Tahun 2013) terlihat nahwa tidak sekolah 16,1 \%, tamat SD dan SLTP 46,4 $\%$, SLTA 23,9 \%, dan Perguruan Tinggi (PT) $13,6 \%$

b. Tingkat Pendapatan.

Produk Domestik Bruto (PDRB) merupakan salah satu cerminan kemajuan ekonomi suatu daerah yang didefinisikan sebagai keseluruhan nilai tambah barang dan jasa yang dihasilkan dalam waktu satu tahun di wilayah tersebut. PDRB Kabupaten Gowa berada pada rengkin ke- 6 dibanding dari 24 Kabupaten /kota se Sulawesi Selatan. Adapun pertumbuhan ekononimnya berada diurutan kedua setelah kota Makassar.

PDRB merupakan salah satu cerminan berhasil tidaknya pelaksanaan pembangunan yang telah dilaksanakan oleh suatu daerah yang dapat bermanfaat sebagai bahan evaluasi hasil-hasil pembangunan di daerah tersebut. Selain dengan melihat peningkatan atau penurunan PDRB (dilihat atas dasar harga konstan) suatu daerah, dapat diperoleh pertumbuhan rill PDRB atau biasa disebut dengan pertumbuhan ekonom daerah itu.

PDRB Kabupaten Gowa tahun 2010 
atas dasar harga berlaku tercatat sebesar 5.082,23 milyar rupiah dan naik menjadi sebesar 5.931,37 milyar rupiah pada tahun 2011 sebesar 1.890,38 milyar rupiah meningkat menjadi 2.007,28 milyar pada tahun 2011. Hal ini menunjukkan bahwa pada tahun 2011 disamping ekonomi Gowa mengalami perkembangan, secara riil ekonomi daerah ini juga mengalami pertumbuhan sebesar 6,20 persen dibanding dengan tahun sebelumnya. Struktur perekonomian Kabupaten Gowa pada tahun 2011 tidak mengalami pergeseran berarti dibanding tahun 2010, dan sumbangan terbesar masih diberikan oleh sektor ertanian, sebesar 43 persen.

Berdasarkan data BPS Kabupaten Gowa yang diperoleh melalui Gowa dalam Angka Tahun 2012 diperoleh angka bahwa PDRB perkapita Gowa mengalami kemajuan dalam lima tahun terakhir. Tahun 2006 sebesar Rp 2. 480. 241, meningkat menjadi Rp 2. 596.751 Tahun 2007, dan meningkat lagi menjadi Rp. 2.723.864 Tahun 2008, dan meningkat lagi menjadi Rp. 2.888.942 Tahun 2009, dan meningkat lagi menjadi Rp.2.897.361 Tahun 2010, dan meningkat lagi menjadi 3.043.579 Tahun 2011. Peningkatan pendapatan perkapita ini tentu saja menjadi harapan tingkat kesejahteraan masyarakat dan berimplikasi pada peningkatan kualitas demokrasi.

c. Tingkat Pelaksanaan keberagamaan.

Kualitas penduduk dari pelaksanaan keberagamaan dapat dilihat dalam dua hal yang pertama secara fisik dan kedua secara sosial-psikologis. Yang pertama dapat dilihat pada jumlah tempat ibadah, perilaku keberagamaan, dan kedua dapat dilihat pada suasana kebatinan masingmasing penganut agama, apakah mereka bebas melaksanakan ibadah tanpa tekanan atau ada gangguan yang membatasi mereka untuk beribadah.
(Rahardjo, 1999).

Sebagaimana diketahui bahwa berdasarkan data BPS Gowa (2011) disebutkan bahwa umumnya $(99,19$ persen) penduduk Kabupaten Gowa menganut agama Islam, sejalan dengan hal tersebut maka tempat peribadatan bagi penganut agama islam terlihat lebih menonjol dibanding agama lain. Sebagai gambaran pada tahun 2011 terdapat 1.289 mesjid, 95 mushallah, dan 4 langgar, sedangkan untuk agama kristen tersedia 23 gereja.

Penganut agama ini relatif aman dan tentram dalam melaksanakan ajaranajarannya, mereka bebas beribadah sesuai dengan petunjuk agama masingmasing tanpa tekanan, apalagi saling mengganggu dari para penganut agama lainnya. Hal ini lebih kondusif lagi karena ada organisasi sosial yang mewadahi kerukunan umumat beragama yang bertujuan untuk melakukan komunikasi dan koordinasi diantara umat beragama.

\section{2) Pengaruh kualitas penduduk dengan kualitas demokrasi dalam kasus pemilihan Gubernur Sulawesi Selatan Tahun 2013 yang diselenggarakan di KecamatanSomba Opu Kabupaten Gowa}

Kualitas penduduk berpengaruh terhadap kualitas demokrasi. Kualitas penduduk yang antara lain meliputi tingkat pendidikan, tingkat pendapatan dan tingkat pelaksanan keberagamaan ketiganya secara bersama-sama berpengaruh secara signifikan terhadap kualitas demokrasi yang antara lain meliputi ada tidaknya money politic dan tingkat partisipasi masyarkat dalam pemilu.

Hasil penelitian ini menunjukkan bahwa ketiga variabel di atas secara bersama-sama berpengaruh terhadap kualitas demokrasi yang meliputi ada tidaknya money politik dan tingkat 
partisipasi politik. Penelitian ini juga menemukan bahwa ketiga indikator kualitas penduduk di atas yang paling tinggi pengaruhnya terhadap money politik adalah variable pendapatan, diikuti oleh variable tingkat pendidikan dan agama. Kalau di analisis lebih jauh maka nampak bahwa hal ini berhubungan dengan kualitas penduduk kabupaten Gowa yang dilihat dari pendapatan dan pendidikan masih rendah, dan pengaruh agama menempati urutan ketiga. Pendidikan dan pendapatan yang rendah memang bisa menjadi celah bagi munculnya money politic, sebab keduanya rentan terhadap suap terutama yang bersumber dari orang-orang yang berduit dan haus kekuasaan, hal ini lebih diperparah lagi jika seseorang kurang memiliki iman yang kuat.

Penelitian ini juga menemukan bahwa ada pengaruh yang signifikan antara pendidikan, pendapatan dan agama terhadap partisipasi masyarakat dalam pemilu. Nampak dalam analisis regresi bahwa pendidikan dan pendapatan kuat pengaruhnya terhadap partisipasi politik. Hal ini tentu saja berbanding terbalik dengan kualitas penduduk di Kabupaten Gowa yang rendah, namun memiliki tingkat partsisipasi antara 70-80\%. Kenyataan ini juga berhubungan dengan realitas politik dibanyak negara, dimana penduduknya kurang berkualitas akan tetapi tingkat partisipasi politiknya tinggi. Lihatlah misalnya beberapa negara berkembang seperti Turki (93,87\%), Vietnam (99,51\%), Rwanda (98,50\%), Cuba $(93,44 \%)$ dan Etiopia (93,44\%). Bandingkan dengan Amerika Serikat, negara yang kondang demokrasi ini memiliki tingkat partisipasi politik (41,59\% pada pemilu legislatif 2010), dan $(57,5 \%$ pada pemilihan presiden tahun2012), bahkan negara peringkat ketujuh paling demokratis yaitu Swiss hanya $(49,10 \%)$ pada pemilu legislatif 2011.

Kalau dianalisis lebih jauh maka partisipasi politik masyarakat bukan disebabkan karena sebuah konstruk kesadaran, melainkan sebaliknya terbangun atas sendi kepentingan ekonomi dari kaum miskin dan tidak terdidik, hal ini sangat bertentangan dengan partisipaisi politik yang sesungguhnya. Partisipasi politik penting, namun bukan saja saat melakukan pemilihan saja, melainkan harus secara holistik, mulai saat formulasi, implemntasi sampai kepada evaluasi. (Simon, Herbert A. 2005. Dan Parsons, Wayne, 2011).

Partisipasi politik secara harafiah berarti keikutsertaan, dalam konteks politik hal ini mengacu pada pada keikutsertaan warga dalam berbagai proses politik. Keikutsertaan warga dalam proses politik tidaklah hanya berarti warga mendukung keputusan atau kebijakan yang telah digariskan oleh para pemimpinnya, karena kalau ini yang terjadi maka istilah yang tepat adalah mobilisasi politik. Partisipasi politik adalah keterlibatan warga dalam segala tahapan kebijakan, mulai dari sejak pembuatan keputusan sampai dengan penilaian keputusan, termasuk juga peluang untuk ikut serta dalam pelaksanaan keputusan.

Konsep partisipasi politik ini menjadi sangat penting dalam arus pemikiran deliberative democracy atau demokrasi musyawarah. Pemikiran demokrasi musyawarah muncul antara lain terdorong oleh tingginya tingkat apatisme politik di Barat yang terlihat dengan rendahnya tingkat pemilih (hanya berkisar 50 - 60 \%). Besarnya kelompok yang tidak puas atau tidak merasa perlu terlibat dalam proses politik perwakilan 
menghawatirkan banyak pemikir Barat yang lalu datang dengan konsep deliberative democracy.

Di Indonesia saat ini penggunaan kata partisipasi (politik) lebih sering mengacu pada dukungan yang diberikan warga untuk pelaksanaan keputusan yang sudah dibuat oleh para pemimpin politik dan pemerintahan.Misalnya ungkapan pemimpin "Saya mengharapkan partispasi masyarakat untuk menghemat BBM dengan membatasi penggunaan listrik di rumah masihng-masing". Sebaliknya jarang kita mendengar ungkapan yang menempatkan warga sebagai aktor utama pembuatan keputusan. Dengan melihat derajat partisipasi politik warga dalam proses politik rezim atau pemerintahan bisa dilihat dalam spektrum: (Dikutip dari http://id.wikipedia.org/wiki/Partisipasi politik).

Artikel dengan judul "Demokrasi, Partisipasi, dan kehadiran di Pemilu" yang ditulis di Tribun Timur oleh Ishak Rahman (5/6/2013) menyimpulkan bahwa tidak ada hubungan langsung antara hadir memberikan suara di tempat pemungutan suara dengan kualitas demokrasi. Penulis memberi contoh beberapa negara yang disebut-sebut kondang dalam demokrasi ternyata tingkat partisipasi warganya dalam pemilu sangat rendah, dan sebaliknya negara yang disebut-sebut sangat otoriter justru tingkat partisipasinya warganya dalam pemilu sangat tinggi, Menurut kandidat PhD Doshisha University, Kyoto Jepang ini bahwa keikut sertaan warga memberikan suara pada pemilu yang dikenal dengan istilah "voter turnaut" ini hanya satu bagian kecil dari partisipasi politik. Disisi lain partisipasi politik juga bukan satu-satunya variabel pengukur kualitas demokrasi. Dikemukakan selanjutnya bahwa Jika kita menganalisa
Democracy Index 2012 The EIU dan database VoterTurnaut oleh International IDEA (Instiute of Democracy and Electoral Asistence) maka dengan sederhana akan dapat dijelaskan bagaimana posisi voter tornout dengan kualitas demokrasi negara-negara di dunia.

Democarcy index adalah penilaian terhadap kualitas demokrasi menggunakan lima variabel makro yaitu proses pemilu dan pluralisme, kebebasan sivil, fungsi pemerintahan, partisipasi poltik, dan budaya politik. Democarcy index 2012 menunjukkan bahwa dari 167 negara di dunia terdapat 25 negara demokrasi penuh (full democracy), 54 negara demokrasi belum sempurna (flawed democracy) , 37 negara rejim campuran (hybrid regime), dan 51 negara rejim otoriter aoutoritharian regim) .

Pada penghujung dekade 2000-an terjadi gejala stagnasi terhadap demokrasi diseluruh dunia. Laporan Demokrasi indeks 2011 diberi judul "Democracy Under Stress" (Demokrasi dalam tekanan), lalu pada tahun 2012 laporan itu berjudul "Democracy is at standstill" (Demokrasi sedang mandeg).

Dalam buku voter Tornout and the Dynamic of electoral and Dynamic of electoral competention in establishet democracies science 1945), Mark N Franklin (2004) memetakan hubungan antara voternout, timeline demokrasi dan dinamika lingkungan global. Kesimpulan yang menarik adalah tingkat kehadiran warga saat pemilu tidak bisa dibandingkan berdasarkan waktu (timeline), dinamika demokrasi baik pada level nasional maupun global, Jika suatu negara mengalami kemerosotan angka voterturnout pada ustau pemilu sebelumnya, umunya penurunan tersebut merupakan kecenderungan global yang 
juga terjadi dibanyak negara, tentu saja beberapa anomali tekanan kondisi domestik bisa saja menjadi faktor yang berkontribusi misalnya penurunan kualitas pemilu atau konflik internal.

Dalam kaitannya dengan persepsi pemilih ada dua faktor yang mempengaruhi keputusan warga untuk hadir atau tidak hadir pada saat pemilihan, pertama pemilu bukan sesuatu yang mempesona, dianggap tidak menarik dan tidak perlu. Persepsi ini muncul jika setelah beberapa pemilu warga tidak merasa manfaat apapu. Warga juga menyaksiskan kekacauan pada pranata -pranata poltik (aktor dan penyelenggara), buruknya manajemen pemilu, mulai pendataan hingga perhitungan dan penetapan hasil.

Kedua, karena sistem yang tercipta telah memuaskan. Mereka percaya bahwa siapapun yang dihasilkan oleh pemilu akan berbuat untuk kepentingan publik. Penurunan juga disebabkan oleh karena terbukanya ruang ruang informasi, dan akses untuk mempengaruhi keputusan publik semakin terbuka.

Dari pemilu legislatif lanjut tulisan di atas di masing-masing negara menunjukkan bahwa rata-rata voter tornout sebagai berikut : demokrasi penuh $(73,63 \%)$, demokrasi belum sempurna (65,72\%) rejim campuran $(63,93 \%)$ dan rejim otoriet (6956\%). Data ini saja menurut penulis sudah bisa menjelaskan bahwa tidak ada hubungan antara kualitas demokrasi dengan voter tornout, Jelas terlihat bahwa rata voter tornout di negara-negara rejim voter tornoutotoriter lebih tinggi dari negaranegara yang lebih demokratis, di dua kategori lainnya (demokrasi belum sempurna dan rejim campuran).

Memang ada fakta bahwa rata-rata voter to.rnout di negara-negara demokratis penuh adalah lebih tinggi jika dibanding dengan tiga kategori lain. Tetapi jika kita mebricdown data ini, maka fakta itu tidak bisa menjustifikasi asumsi bahwa semakin tinggi voter tornout maka akan semakin demokratis negara tersebut.

Selanjutnya dikemukakan bahwa pertama, negara dengan voter tornout tertinggi adalah Laos yaitu 99,69\% pada pemilu 2011. Sementara di Index Demokrasi negara ini berada pada kategori rejim otoriter (peringkat ke156). Dikategori ini juga terdapat enam negara voter tornout di atas $90 \%$ yaitu Turmenistan (9337\%) , Equitorial Guinea $(96,45 \%)$, Vietnam $(99,51 \%)$, Rwanda 98,50\%), Cuba $(96,89 \%)$ dan Ethiopia $(93,44 \%)$. Kedua dari 25 negara berkategori demokrasi penuh 12 di antaranya memilki voter tornout pada pemilu terakhirnya di bawah 70\% (ambang batas ideal versi IDEA). voter tornout Amerika Serikat adalah 4159\% pada pemilu legislatif 2010 dan 57,5\% pada pemilihan presiden 2012, AS berada pada peringkat paling demokratis./ Bahkan negara peringkat ke 7 paling demokratsi yaitu Swis angka voter tornout $49,10 \%$ pada pemilu legislatif 2011.

Kalau dianalisis lebih jauh maka terdapat anomali politik bahwa seharusnya partisipasi politik hanya datang dari mereka yang memiliki kecakapan-kecakapan politik dengan syarat memilki tingkat pendidikan dan pendapatan yang bagus, memilki kesadaran keberagamaan yang baik, namun kenyataannya justru datang dari kaum miskin dan tidak terdidik. Partisipasi masyarakat dalam pemilihan Gubernur Sulawesi Selatan Tahun 2013 yang diselenggarakan di Kecamatan Somba Opu Kabupaten Gowa yang mencapai 75 sampai $85 \%$ \% bisa disebut 
semu dan bukan menggambarkan partisipasi yang sesungguhnya, bahwa partisipasi seperti itu hanya sebagaian kecil dari sebuah partisipasi yang sesungguhnya. Dengan begitu bisa disebut bahwa kualitas demokrasi hanya bisa ditemukan pada penduduk yang berkualitas.

\section{E. PENUTUP}

Kualitas Penduduk di Kabuaten Gowa dilihat dari tingkat pendidikandan pendapatan masih rendah, namun kualitas demokrasi dilihat dari partisipasi Dalam Kasus Pemilihan Gubernur Sulawesi Selatan Tahun 2013cukup tinggi sekitar 75 sampai $85 \%$.

Pengaruh Kualitas Penduduk Dengan Kualitas Demokrasi Dalam Kasus Pemilihan Gubernur Sulawesi Selatan Tahun 2013 yang diselenggarakan di Kecamatan Somba Opu Kabupaten Gowa berdasarkan pengujian regresi yang dihasilkan adalah : 14,534 + 0,273 $\mathrm{X}_{1}+$ $0,335 \mathrm{X}_{2}+0,079 \mathrm{X}_{3}$. Terlihat bahwa variable pendapatan memberikan kontribusi paling besar, diikuti oleh variable tingkat pendidikan dan agama. Kontribusi ketiga variable ini secara bersama-sama terhadap money politic sebesar 0,413 (41,3\%). Pengujian regresi menunjukkan bahwa ada pengaruh (meskipun kecil) secara bersama-sama antara variable bebas tingkat pendidikan $\left(\mathrm{X}_{1}\right)$, Pendapatan $\left(\mathrm{X}_{2}\right)$, dan Agama $\left(\mathrm{X}_{3}\right)$ terhadap variable terikat yakni Tingkat partisipasi $\left(\mathrm{Y}_{2}\right)$ dengan signifikansi 0,000. Persamaan regresi yang dihasilkan adalah : 3,913+ $0,067 \mathrm{X}_{1}-0,019 \mathrm{X}_{2}+0,001 \mathrm{X}_{3}$. Terlihat bahwa variable pendidikan memberikan kontribusi paling besar, disusul pendapatan dan agama terhadap tingkat partisipasi. Kontribusi ketiga variable ini secara bersama-sama terhadap money politik sebesar $0,215(21,59 \%)$.

\section{DAFTAR PUSTAKA}

Abdullah Rozali. 2005. Pelaksanaan Otonomi Luas Dengan Pemilihan Kepala Daerah Secara Langsung, Radja Grafindo Persada, Jakarta.

Alfian. 1990. Transpormasi Sosial Buda ya dalam Pembangunan Nasional. Jakarta: Universitas Indonesia Press.

Back, Kurt.W. 1977. Social Psychology. New York: John Willey and Sons. Inc.

Budiman, A. 1995. Teori Pembangunan dan Dunia Ketiga. Jakarta: Gramedia.

Budiarjo, Miriam.2009. Dasar-Dasar Ilmu Politik :Gramedia Pustaka , Jakarta:

BKKBN, 2012. Bahan Seminar Koaliasi Kependudukan yang diselenggarakan di Makassar Tanggal 6 Desember 2012

Dahl, Robert, 1985. Analisa Politik Moderen, Bumi Aksara, Jakarta

Dan Nimmo. 2000. Komunikasi Politik. Remaja Karya. Jakarta

Frank, A.Gunder. 1984. Sosiologi Pembangunan dan Keterbelakangan. Pustaka Pulsar, Jakarta

Harry B. Harmadi, Sony, 2013, Makalah yang disampaikan pada Rapat Kerja Koalisi Kependudukan di Makassar 6 Desember 2012

Herbert A. 2005. Public Administration : Third Printing, New Brunswick and London : Transaction Publishers

Kantor Menteri Negara Kependudukan/BKKBN, 1994 Grand Design Pembanguna Kependudukan 2010 - 2015, Jakarta. 
Muhaimin Yahya dan MacAdrews. 1977. Masalah-masalah Pembangunan Politik. Gadjah Mada University Press, Yogyakarta

Ndraha, Taliziduhu. 1997. Metodologi Ilmu Pemerintahan .Rineka Cipta, Jakarta

Parsons, Wayne, 2011. Public Policy : Pengantar Teori dan Praktik Analisis Kebijakan, Jakarta.

Kencana,

Rahardjo, Dawam. 1999. Masyarakat Madani, Agama, Kelas Menengah dan Perubahan Sosial, LP3ES, Jakarta

Ritzer, George and J. Goodman Douglas. 2004. Teori Sosiologi Modern, Diterjemahkan dari Karya aslinya " Modern Sociological Theory" Oleh Alimandan. Jakarta: Kencana Prenada Media Group.

Syafi'ie, 2007. Pengantar Ilmu Pemerintahan, Refika Aditama, Bandung

Sugiyono . 2007. Statika , Alfabet, Jakarta

Shibutani, T. 1986. Social Processes. An Introduction to Sociology. Berkeley: University of California.

Sztompka, Piotr. 2004. Sosiologi Perubahan Sosial. Prenada. Jakarta

Singarimbun, Masri dan Efendi Sofian. 1983. Metode Penelitian Survai, LP3ES, Jakarta

Sanit, Arbi dkk. 2003. Menggugat Partai Politik.. LIP FISIP UI, Jakarta

Thoha, Miftah, 2008. Perilaku Organisasi, Konsep Dasar dan Aplikasinya. Jakarta:Raja Grafindo Persada.
Taufiq Nugroho, 2009 .diakses melalui internet 25 Februari 2009

Wiyono. 2000. Organisasi Kekuatan Sosial Politik di Indonesia. Alumni, Bandunghttp://id.wikipedia.org/wi ki/Pemilihan umum di Indonesia (diakses tgl 24 april 2012).

http://id.wikipedia.org/wiki/Partisipasi politikhttp//id.wikipedia.org/wiki/ Pemeilihan Umum, (diakses 16 Mei 2013)

Dokumen :

Undang-Undang RI Nomor 10 Tahun 2008 Tentang Pemilu 2009. Citra Umbara. Bandung

Undang-Undang RI Nomor 22 Tahun 2007 Tentang Pemilu.Cemerlang. Jakarta

Undang-undang Nomor 52 Tahun 2009 tentang

Perkembangan

Kependudukan dan Pembangun 